\title{
Challenges and Adherence to Standard Precautions for Prevention of Percutaneous Injuries and Exposure to Blood Borne Pathogens in Clinical Practice: A Review
}

\author{
Theophilus Ogochukwu Nwankwo ${ }^{*}$, Godwin Ugonna Odo², Matthew Ikechukwu Eze1, \\ Ijeoma Victoria Ezeome1, Uchenna Anthony Umeh ${ }^{1}$ \\ ${ }^{1}$ Faculty of Medicine, University of Nigeria, Nsukka, Nigeria \\ ${ }^{2}$ University of Nigeria Teaching Hospital, Enugu, Nigeria \\ Email: *theophilus.nwankwo@unn.edu.ng, ‘theonwankwo@gmail.com, danmemo@yahoo.com, matthew.eze247@unn.edu.ng, \\ Ijeoma.ezeome@unn.edu.ng, Anthony.umeh@unn.edu.ng
}

How to cite this paper: Nwankwo, T.O., Odo, G.U., Eze, M.I., Ezeome, I.V. and Umeh, U.A. (2020) Challenges and Adherence to Standard Precautions for Prevention of Percutaneous Injuries and Exposure to Blood Borne Pathogens in Clinical Practice: A Review. Open Journal of Preventive Medicine, 10, 195-216.

https://doi.org/10.4236/ojpm.2020.108014

Received: January 16, 2020

Accepted: August 3, 2020

Published: August 6, 2020

Copyright $\odot 2020$ by author(s) and Scientific Research Publishing Inc. This work is licensed under the Creative Commons Attribution International License (CC BY 4.0).

http://creativecommons.org/licenses/by/4.0/ (c) (i) Open Access

\begin{abstract}
Background: Standard Precautions (SP) was introduced by Centre for Disease Control to minimise the risks of disease transmission in the process of healthcare. Many factors are thought to influence the knowledge and the practice of these measures. Objective: To review challenges and adherence to SP for the prevention of percutaneous injuries and exposure to patients' blood in clinical practice. Methods: The World Wide Web sites such as, Pub Med central, Google scholar were searched using key words such as percutaneous, needle stick injuries, standard precautions, adherence. Relevant articles were reviewed and included based on defined criteria. Results: The prevalence of needle stick injuries (NSI) varies among health care workers (HCWs) and across countries and is as high as $73 \%$ among some groups. The knowledge of SP varied among HCWs in different nations; however the practice of SP was noted to be lower than knowledge across most studies. Majority of HCWs in developing countries that sustained NSI failed to report the incident to appropriate authorities. Adherence to Standard Precautions is influenced by lack of proper training, poor supplies, low commitment of HCWs and health facility managers etc. Conclusion: Needle stick injuries and exposure to patients' blood remain a risk for disease transmission among HCWs. Despite appreciable knowledge of standard precautions, the practice has remained low across the globe. Factors that had positive influence on practice of SP such as use of devices with safety features, adherence to infection control guideline, comfortable working environment, repeated and intense training etc. should be adopted and promoted.
\end{abstract}




\section{Keywords}

Percutaneous Injuries, Prevention, Standard Precautions, Adherence

\section{Introduction/Background}

Health care workers (HCWs) are at risk of acquiring blood and body fluid borne infections such as hepatitis and human immune deficiency virus (HIV) etc. through accidental injuries and direct exposure to body fluids [1] [2] [3]. These body fluids include cerebrospinal fluid (CSF), peritoneal fluid, pleural fluid, pericardial fluid, synovial fluid breast milk, semen and urine. Saliva, vomitus, perspiration, sputum and nasal secretions are less established sources of infection [4]. The World Health Organization (WHO) had reported a worldwide annual proportion of HCWs exposed to blood borne pathogens as $2.6 \%$ for hepatitis $\mathrm{C}$ virus (HCV), $5 \%$ for hepatitis B virus (HBV) and $0.5 \%$ for HIV. Meanwhile, $40 \%$ - $65 \%$ of HBV and HIV infections among HCWs are due to percutaneous injuries. The risk of injuries at work place is higher in developing countries compared to the developed nations [5] [6]. This is attributable to more prevalent blood borne pathogens in low income countries especially sub Saharan African countries.

The effect of percutaneous injuries ranges from psychological trauma through chronic diseases to death [7] [8]. The safety of HCWs is therefore a global health concern [9] as it is important that measures are in place for protection. Universal Precautions which later translated to Standard Precautions was introduced by Centre for Disease Control (CDC). Many developed countries and few developing countries have introduced needle stick injuries prevention activities guidelines, for example the USA needle stick safety and prevention Act was enacted 2000 and became active in 2001 [10]. The European Union legislation to improve safety and health of workers was introduced in 1989 and in 2010 the European council adopted Directive 2010/32/EU on prevention from sharp injuries in the hospitals and healthcare sector, which was specifically developed to protect HCWs from risk of occupational NSI and subsequent infection with HIV and other blood borne pathogens [11].

Universal precaution is defined by the Centre for Disease Control (CDC) as a set of precautions or actions designed to prevent the transmission of $\mathrm{HBV}, \mathrm{HCV}$, HIV and other body fluid or blood borne pathogens when providing first aid or health care [4]. The aim is to protect both the HCWs and the uninfected patients [4]. It is composed of four standard practices comprising hand washing, safe handling and disposal of sharps, safe decontamination of instruments and the use of protective barriers like aprons, gloves, goggles and boots. Additional protection may, however, be required in cases of mumps, rubella, tuberculosis, influenza and pertusis. The practice was first introduced in 1985 but was readjusted in 1987 by a set of rules known as Body Substance Isolation [12]. Then, in 
1996, universal and body substance isolation were replaced by the latest approach known as Standard Precautions [12].

However, Universal Precautions have continued to be implemented worldwide, though, the knowledge and implementation have continued to be subjects of debate. And even where the knowledge and understanding of universal precautions appear adequate, financial limitations in low resource settings may limit availability and has also been seen as discrimination against patients and considered stigmatization especially against HIV patients [13] [14].

The above limitations and the continued exposure of HCWs to injuries and blood-borne infections are the reasons studies regarding universal precautions and percutaneous injuries have continued.

Our objective is to review available literatures on prevalence and incidences of percutaneous injuries and accidental exposure to patients' blood and the challenges of and adherence to standard precautions among medically exposed individuals.

\section{Methods}

\section{Search methods}

The World Wide Web was searched using key words and their various combinations such as:

Percutaneous Injuries, Prevention, developing countries.

Percutaneous injuries, health worker, prevention, developing countries.

Percutaneous Injuries, Prevention, developed countries.

Percutaneous injuries, health worker, prevention, developed countries.

Percutaneous injuries, standard precautions, health workers, clinical practice.

Percutaneous injuries, universal precaution, health workers, clinical practice.

Exposure to blood borne pathogens and standard precaution.

Percutaneous injuries, Standard precaution, adherence, challenges, developing countries.

Percutaneous injuries, Standard precautions, adherence, challenges, developed countries.

Percutaneous injuries, Standard precautions, adherence, challenges, hospital management, developed countries.

The web sites searched include Pub Med central, African journal on line, PubMed UK, Medscape, Google scholar, Google web and Medknow. The web search was limited to articles published between the years 1999 to 2018 . We identified articles both full and abstracts and other publications that researched into prevalence of percutaneous injuries and exposure to patients blood, attitude, knowledge and application of standard precautions to prevent blood borne pathogens, Also articles that involved hospital management predispositions to staff training in the used of standard precautions and provision of the requirements for the practise of standard precautions were also assessed and evaluated.

The data extraction focused on: 
The year of Publication

Country and the region in which research was conducted.

The type of study

The study population and its characteristics and the number of research subjects.

Parameters extracted include, year and country of study, the number of subjects and type of study, prevalence and incidence of percutaneous injuries or exposure to patient blood among health workers studied, group of health workers studied, incidences of exposure reported, level of knowledge of and attitude to standard or universal precautions, practice and adherence of health workers to standard precautions, challenges to good practice of standard or universal precaution, reported methods and factors that improve practice of and adherence to standard or universal precautions.

The Inclusion criteria include:

1) Original research articles on the subjects that are either cross-sectional studies, descriptive or randomised studies that focused on prevalence of percutaneous injuries and exposure to patients blood borne pathogens, knowledge, attitude, practice and determinants of practice towards standard precautions for prevention of blood borne pathogens.

2) Research articles focusing on attitudes of health management to practice of standard precautions and provision of equipment necessary for prevention of percutaneous injuries and exposure to patients' blood.

3) Articles published in the last 20 years between 1999-2018, to accommodate differences and possible advancements in the protective equipment and other practices between developed and developing countries.

Review methods:

The abstracts and full articles downloaded from the web were independently read and evaluated by two of the authors for relevance and possible selection. Articles that met the inclusion criteria were selected for in-depth review.

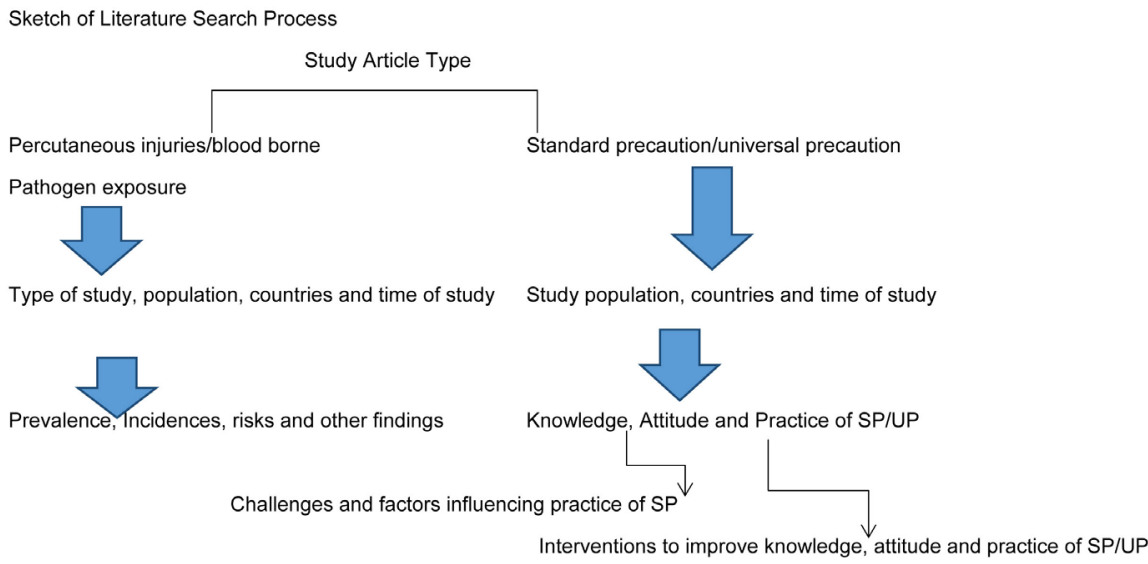

\section{Result}

A total 529 articles and abstracts were evaluated for inclusion criteria. 67 articles 
were reviewed and chosen from developing countries while 24 articles were selected after review from developed countries. The articles from developing countries had 23302 subjects studied while those from developed studied 8945 subjects

Needle sticks injuries (NSI) and exposure to blood and body fluids (EBBF):

The prevalence and incidences of NSI and BBFE across health workers and medically exposure persons were recorded from 34 studies in the review. The prevalence varied depending on the population of healthcare workers or students studied. It ranged from $17 \%$ among HCWs in a tertiary hospital in India [15] to $54 \%$ and $72.1 \%-73 \%$ among nurses and midwifery students in Iran [16]. Most common activity that led to NSIs among nurses was recapping of needle especially double hand recapping [17]. Studies that reported on incidence and prevalence of percutaneous injuries, needle stick injuries and exposure to blood and body fluid of patient are shown in Table 1. A study in Botswana involving 885 randomly selected HCWs reported PI prevalence of $48.9 \%$ which were significantly higher among nurses odd ratio $3.49(\mathrm{CI}=2.02-6.08) \mathrm{p} \leq 0.001$ [18]. Parithram et al. in India reported NSI prevalence of $27.5 \%$ with $41.8 \%$ of them occurring during needle recapping [19]. Several studies across 6 different developing countries reported on prevalence of percutaneous injuries ranging from $19 \%$ to $67.9 \%$ and noted a preponderance of nurses in the range of $28 \%$ to $70 \%$ being mostly involved [20]-[27]. Bidira et al. in their study in Ethiopia reported that the risk of NSI was tripled in nurses with lower level of knowledge [28]. Varying percentage of staff that had needle stick injuries reported to appropriate authority. Bolarinwa et al. in their study among 247 primary health care workers in Nigeria found the least (19.5\%) of those that had needle stick injuries reporting to appropriate authority, [29] Nwankwo et al. in their study among surgical resident in a training institution in Nigeria reported NSI prevalence of $67.5 \%$ and noted that $76.9 \%$ of the respondents involved ignored the incidents, Denic et al. in Kenya 40.1\%, Raghavendran et al. 2006 in United Kingdom noted that $66 \%$ of nurses reported sustained needle stick injuries [23] [30] [31]. Guest et al. in the study among nurse in Australia reported that $90 \%$ of nurses reported NSI to appropriate authority when involved [21]. Perez-diaz et al. in their study in Columbia of 2403 HCWs exposed to blood borne pathogens, noted that NSI was the highest (86.5\%) with one sero-conversion [32]. Hanafi et al. in their study reported that $8.2 \%$ of NSI involved high risk patients and only $25.3 \%$ of those involved in NSI reported, Physicians are most unlikely to report [33]. Omar et al. in Kuwait reported that the prevalence of incident exposure among at risk HCWs was $0.7 \%$ with NSI being the Commonest at $75.9 \%$ [34]. Guest et al. reported annual incidence of $7.2 \%$ (95\% CI 5.9 - 8.7) in Australia which was higher in private hospitals (17.9\% compared to public hospitals $15.2 \% \% 0 \%$ reported lack of safety engineered medical device in the centre [21].

In USA, Beckman et al. in their study of 153 hospital in Virginia USA reported annual PI of 5.3/100 personnel in 106 hospitals while Grimond et al. in their national survey of 125 hospital in 29 states reported sharp incidence of 
Table 1. Prevalence and incidences of NSI and EBBF.

\begin{tabular}{|c|c|c|c|c|c|c|c|}
\hline $\mathrm{S} / \mathrm{N}$ & Authors and year & Country & Population/type of study & incidence & Prevalence & $\begin{array}{l}\text { Group most } \\
\text { affected }\end{array}$ & $\begin{array}{c}\text { Reported } \\
\text { Incidences \% }\end{array}$ \\
\hline 1 & $\begin{array}{c}\text { Punia et al. } 2014 \\
{[15]}\end{array}$ & India & Cross-sectional of $165 \mathrm{HCWs}$ & & $17 \%$ & - & - \\
\hline 2 & $\begin{array}{c}\text { Jamu et al. } 2016 \\
{[18]}\end{array}$ & Botswana & Cross-sectional of $885 \mathrm{HCWs}$ & & $11 \% / 6$ months & $\begin{array}{l}\text { Nurses (OR: } \\
4.1, \text { Drs 4.2) }\end{array}$ & \\
\hline 3 & $\begin{array}{c}\text { Izadi et al. } 2015 \\
\text { [22] }\end{array}$ & Iran & C/S of 309 HCWs & $26.90 \%$ & - & Nurses (63.9\%) & - \\
\hline 4 & Jahangiri et al. 2016 & Iran & 168 registered nurses & $76 / 56 \%$ & - & & $60.20 \%$ \\
\hline 5 & $\begin{array}{c}\text { Jayanth et al. } 2009 \\
\text { [20] }\end{array}$ & India & C/S of $296 \mathrm{HCWs}$ & $\begin{array}{c}\text { Nurses } 28.4 \% \text {, Drs } \\
21.6 \%\end{array}$ & - & Nurses@ 28.4\% & - \\
\hline 6 & Parithran et al. [19] & India & 200 Dental Staff & - & $27.50 \%$ & & - \\
\hline 7 & Moodley et al. [23] & South Africa & Dental staff and students & - & $22 \%$ & Students@76\% & 81 \\
\hline 8 & Mbaisi et al. [41] & Kenya & $\mathrm{C} / \mathrm{S}, 305 \mathrm{HCWs}$ & - & $19 \%$ NSI/25\% & Nurses@ 50\% & - \\
\hline 9 & $\begin{array}{c}\text { Denic et al. } 2015 \\
{[31]}\end{array}$ & Serbia & $\mathrm{C} / \mathrm{S}, 983 \mathrm{HCWs}$ & - & $29.60 \%$ & & 40.2 \\
\hline 10 & $\begin{array}{l}\text { Bolarinwa et al. } \\
\quad 2011 \text { [29] }\end{array}$ & Nigeria & C/S, 247 PHCWs & - & $31 \%$ & - & 19.5 \\
\hline 11 & $\begin{array}{c}\text { Bidira et al. } 2014 \\
\text { [28] }\end{array}$ & Ethiopia & C/S, 211 Nurses & - & $39.30 \%$ & & - \\
\hline 12 & $\begin{array}{c}\text { Talaat et al. } 2003 \\
{[17]}\end{array}$ & Egypt & C/S, 1485 HCWs & - & $35.6 \% / 3$ months & & - \\
\hline 13 & $\begin{array}{c}\text { Hanafi et al. } 2011 \\
\text { [33] }\end{array}$ & Egypt & C/S, HCWs & - & 63.3 & & - \\
\hline 14 & Qazi et al. [75] & Pakistan & C/s 198 HCWs & - & $50 \%$ & & - \\
\hline 15 & $\begin{array}{c}\text { Kuruuzum et al. } \\
2008[76]\end{array}$ & Turkey & $\mathrm{C} / \mathrm{S}, 350 \mathrm{HCWs}$ & - & $58 \%$ & Nurses@ 74.6\% & \\
\hline 16 & $\begin{array}{c}\text { Askarian et al. } 2015 \\
{[16]}\end{array}$ & Iran & C/S, 137 HCWs & - & $72.1-73.7 \%$ & & \\
\hline 17 & $\begin{array}{c}\text { Nwankwo et al. } \\
2011[30]\end{array}$ & Nigeria & Surgical resident doctors & & (PI/EBBF) $67 \%$ & & \\
\hline 18 & $\begin{array}{c}\text { Nouetchognou et } \\
\text { al. [40] }\end{array}$ & Cameroon & $\mathrm{C} / \mathrm{S}, 150 \mathrm{HCWs}$ & - & 36.7 EBBF & & \\
\hline 19 & $\begin{array}{c}\text { Laisser et al. } 2017 \\
{[77]}\end{array}$ & Tanzania & C/S, 277 Randomly selected HCWs & $1.96 / 100$ person/year & $59 \%$ & & \\
\hline 20 & $\begin{array}{c}\text { Hysieh et al. } 2006 \\
{[78]}\end{array}$ & Taiwan & HCWsover 3 years & 4.4/100person/year & & Nurses@60.0\% & \\
\hline 21 & $\begin{array}{c}\text { Wang et al. } 2015 \\
\text { [79] }\end{array}$ & China & Transfusion centre & & & Nurses@ 49.5\% & \\
\hline 22 & $\begin{array}{c}\text { Bhardwaj et al. } 2014 \\
{[80]}\end{array}$ & Malaysia & HCWs in orthopaedic ward & & $20.90 \%$ & & \\
\hline 23 & Moro et al. [81] & $\begin{array}{l}\text { Dorminican } \\
\text { Republic }\end{array}$ & HCWs in 440 hospital/clinics & & $22.30 \%$ & & \\
\hline 24 & Salehi et al. 2010 [3] & Afghanistan & $\mathrm{C} / \mathrm{S}, 950 \mathrm{HCWs}$ & $12 / 230()$ & $72 \%$ & Obygn@ 96.1\% & \\
\hline
\end{tabular}




\section{Continued}

\begin{tabular}{|c|c|c|c|c|c|c|c|}
\hline 25 & $\begin{array}{l}\text { Zaidi et al. } 2012 \\
\text { [82] }\end{array}$ & United Emirate & $\mathrm{C} / \mathrm{S}, 230 \mathrm{HCWs}$ & & & & 66 \\
\hline 26 & $\begin{array}{l}\text { Raghavendran et al. } \\
\text { [23] }\end{array}$ & United Kingdom & Survey of 258 Critical care staff & 373PEI/3years, $7.2 \%$ & $\begin{array}{c}53 \% / \text { years of } \\
\text { practice }\end{array}$ & & \\
\hline 27 & $\begin{array}{l}\text { Smith et al. } 2005 \text {, } \\
\text { [26] }\end{array}$ & Australia & Survey of 373 cases of PI & & $38.9 \%$ needle stick & $63.50 \%$ & \\
\hline 28 & $\begin{array}{l}\text { Guest et al. } 2014 \\
\qquad[21]\end{array}$ & Australia & $256 / 1100$ nurses & $13,041 \mathrm{BBFE} / \mathrm{yr}$ & - & & $90 \%$ \\
\hline 29 & $\begin{array}{l}\text { Venier et al. } 2007 \\
\qquad[25]\end{array}$ & France & HCWs In 375 Health Centres & 249 exposure/yr & $0.7 /$ at risk $\mathrm{HCW}$ & & \\
\hline 30 & Omar et al. $[34]$ & Kuwait & Retrospective, $249 \mathrm{HCWs}$ & $\begin{array}{l}60 \text { NSIs/2yrs } 4 \\
\text { months }\end{array}$ & $75 \%$ NSI & & \\
\hline 31 & $\begin{array}{l}\text { Falafel et al. } 2007 \\
\qquad[83]\end{array}$ & Greece & 3.48/100FTEY and @risk staff & $24.0 / 1000 \mathrm{Obs}$ & & & \\
\hline 32 & $\begin{array}{l}\text { Grimond et al. } 2013 \\
{[24]}\end{array}$ & USA & HCWs in 129 hospitals & $4.8 / 100 \mathrm{OBs} / \mathrm{yr}$ & $100 \mathrm{NSI} / 100 \mathrm{OBs}$ & & \\
\hline 33 & $\begin{array}{l}\text { Yoshikawa et al. } \\
\quad 2013 \text { [35] }\end{array}$ & Japan & 5463 HCWs from 67 Hosp & & & & \\
\hline 34 & Rice et al. 2015 [36] & England & $\begin{array}{l}10 \text { years analysis of Per \& } \\
\text { muco-cutaneous Exposures }\end{array}$ & & $\begin{array}{l}2957 \text { Sharp injury } \\
\text { recorded in } 10 \text { years }\end{array}$ & & - \\
\hline 35 & $\begin{array}{l}\text { Wicker et al. } 2008 \\
\text { [37] }\end{array}$ & Germany & $\begin{array}{l}\text { Case control study involving } 13358 \text {, } \\
20163 \text { \& } 13381 \text { tested for HbsAg, }\end{array}$ & & $\begin{array}{l}432 / 1342(32.3 \%) \\
\text { NSIs }\end{array}$ & & \\
\hline 35 & $\begin{array}{l}\text { Shiao et al. } 2002 \\
\text { [39] }\end{array}$ & Taiwan & $\begin{array}{c}\text { AntiHCV, \& HIV } 1085 \text { patient } \\
\text { tested for HBV, HCV, HIV }\end{array}$ & & $\begin{array}{c}\text { 7550NSI by } 8645 \\
\text { HCWs }\end{array}$ & - & 23.3 \\
\hline
\end{tabular}

$\mathrm{OB}=$ occupied beds, $\mathrm{C} / \mathrm{S}=$ Cross sectional, $\mathrm{HCW}$ s = Healthcare worker.

\section{0/1000 occupied beds [35].}

In France Venier et al. surveyed 375 medical centres consisting of $15 \%$ of French medical centres and reported annual incidence of 13,031 Blood and body fluid exposures with NSI consisting 72\%. Yoshikawa et al. in Japan in their survey of 5463 respondents selected from 67 Japanese hospitals reported NSI incidence of 4.8/100 occupied beds (95\% CI 4.1 - 5.6) and sharp injuries tend to be higher in larger centres and in workers less than 40 years [25].

In England, Rice et al. reported 2957 sharp injuries involving source patients with blood borne infection in their 10 year review, with a trend that increased with years noting a higher episode of 67\% higher in 2011 compared to 2002 [36].

Wicker et al. in their study estimated the risk of infection to common blood pathogen and reported highest risk of exposure was in internal medicine, 4.56, 5.88 and 6.16 for HBV, HCV and HIV respectively. The risks in Obstetrics and Gynaecology and Surgery departments were $(0.37,1.35 \& 0.37)$ and $0.44,1.07 \&$ $0.16)$ respectively [37].

A study by Yoshikawa et al. in Japan, that surveyed 5463 participants in 67 hospitals, reported NSI incidence of $4.8 / 100$ (95\% CI, 4.1 - 5.6) the incidence tended to be higher among workers less than 40 years, and those working in pa- 
tients room and operating theatres [38].

Shiao et al. in their study in Taiwan noted that 7550 NSIs were reported by 8645 HCWs with estimated 308 - 924 being at risk of contacting HBV, 334 - 836 for HCV. Nurses had the highest risk for NSI (543) and for contacting HBV (543) and, HCV596) 1762 HCWs are at risk of sero-conversion annually with $64.7 \%$ likely to be nurses [39]. Mbaisi et al. in their study of 305 respondents reported preponderance of nurses were involved in PI during stitching and in the Obstetrics and gynaecology [40]. Nouetchognou reported that $36.7 \%$ of 150 HCWs studied were exposed to blood and body fluids, majority of them worked in surgical depaetment [41].

Knowledge, Attitude and Practice of Universal or standard precautions for prevention of PI/NSI/EBBF in developing and developed countries:

\section{Developing Countries:}

Table 2 shows some of the indices of knowledge, attitude and practice of standard precautions. Knowledge level of standard precautions and protective equipment varies from 15\% recorded by Abdulrahem et al. in Northern Nigeria to $90 \%$ by Ogoinia et al. reported in the Southern Part of the same Country [42] [45]. Bolagii-Osagie et al. in their study in Nigeria reported high knowledge of UP among midwives and that more than 50\% practice UP [44]. Ibeziakor et al. 2006 and Ndu et al. 2017 reported SP knowledge of 50\% and 76.2\% respectively; the later reported that safety practice was higher among Doctors than other health workers [45] [46].

The practice of SP was lower than knowledge across most studies. Sado et al. in Western Nigeria reported 31.9\% of HCWs studied always recap needle with preponderance among trained nurses [47]. Amora et al. studied $421 \mathrm{HCWs}$ in Northern Nigeria and reported that $77.9 \%$ had good knowledge of SP, $8.1 \%$ had had any form of training on SP, they reported poor compliance to UP, with 98.0\% indicating lack of protective equipment as reason for non compliance [48]. Reda et al. in their study of 475 HCWs in 10 hospital and medical centres in Ethiopia reported $46.9 \%$ had knowledge of SP with $30.5 \%$ being positively disposed to it and $80 \%$ regularly observe SP in the practice [2]. Tesfay et al. reported that $92.4 \%$ of 234 HCWs drawn from 4 hospitals in the region knew all type of protective equipment but only 50\% made use of them [49]. Gebresilassie et al. studied 483 HCWs in Ethiopia and reported that $42.9 \%$ had good practice of SP, with the odd of good practice of SP being 2.5. About $2 / 3$ of the studied population has had training in SP [50]. Eskander et al. and Mortada et al. in their studies of nurses and doctors in Egypt reported that $57.1 \%$ and $57.5 \%$ complied with standard precautions in their duties, while $63.6 \%$ of nurses had unsatisfactory knowledge [17] [51]. While Hanafi et al. reported a knowledge and practice levels of $58.7 \%$ and $46.3 \%$ respectively in the same country [30]. In Uganda, Wasswa et al. studied 202 HCWs and reported SP knowledge level of 6/8 (75\%) while $72.6 \%$ had been trained in SP [52].

Pati et al. in Odisha India studied 32 HCWs working in Sub-district hospital 
Table 2. Attitude knowledge and practice of standard precaution.

\begin{tabular}{|c|c|c|c|c|c|c|c|c|c|c|c|c|}
\hline $\mathrm{S} / \mathrm{N}$ & Author/year & Country & $\begin{array}{c}\text { Population/Type } \\
\text { of study }\end{array}$ & $\begin{array}{c}\text { Good/ } \\
\text { adequate } \\
\text { Knowledge }\end{array}$ & $\begin{array}{l}\text { Positive } \\
\text { Attitude }\end{array}$ & $\begin{array}{c}\text { Gen } \\
\text { Practice }\end{array}$ & $\begin{array}{c}\text { Hand } \\
\text { washing }\end{array}$ & $\begin{array}{c}\text { Wearing of } \\
\text { gloves }\end{array}$ & $\begin{array}{c}\text { Wearing of } \\
\text { Apron/masks }\end{array}$ & $\begin{array}{c}\text { Eye } \\
\text { protection }\end{array}$ & $\begin{array}{l}\text { Don't } \\
\text { recap } \\
\text { Needle }\end{array}$ & $\begin{array}{l}\text { Proper } \\
\text { Sharp } \\
\text { disposal }\end{array}$ \\
\hline 1 & $\begin{array}{l}\text { Punia et al. } \\
2014 \text { [15] }\end{array}$ & India & $\mathrm{C} / \mathrm{S}, 162 \mathrm{HCWs}$ & & - & - & $95 \%$ & $77 \%$ & $28 \%$ & $22 \%$ & - & - \\
\hline 2 & $\begin{array}{c}\text { Pati et al. } 2013 \\
{[2]}\end{array}$ & India & $\begin{array}{l}32 \text { HCWs in Sub } \\
\text { District Hospital }\end{array}$ & $90.90 \%$ & & & $50 \%$ & & $31 \%$ & $38 \%$ & & \\
\hline 3 & $\begin{array}{c}\text { Jain et al. } 2012 \\
{[54]}\end{array}$ & India & $\begin{array}{c}329 \text { nurses and } 71 \\
\text { doctors }\end{array}$ & $55.30 \%$ & - & $52 \%$ & & - & & & - & - \\
\hline 4 & $\begin{array}{c}\text { Das et al. } 2016 \\
{[84]}\end{array}$ & India & $\begin{array}{l}\text { C/S study of } 132 \\
\text { interns }\end{array}$ & $\begin{array}{c}\text { Hand } \\
\text { washing } 82 \% \text {, } \\
\text { wearing } \\
\text { gloves } 82.6 \%\end{array}$ & & & $64 \%$ & & & & $47.90 \%$ & $62.50 \%$ \\
\hline 5 & $\begin{array}{c}\text { Holla et al. } \\
2014 \text { [55] }\end{array}$ & India & $\begin{array}{l}\mathrm{C} / \mathrm{S}, 178 \text { health } \\
\text { care professionals }\end{array}$ & & $97.20 \%$ & & $75.50 \%$ & $77.50 \%$ & $46.60 \%$ & $31.50 \%$ & $51.70 \%$ & $87.60 \%$ \\
\hline 6 & $\begin{array}{c}\text { Askarian et al. } \\
2002[16]\end{array}$ & Iran & $\begin{array}{c}\text { C/S study of } 137 \\
\text { dental \& } 208 \\
\text { midwifery } \\
\text { students }\end{array}$ & $85 \%$ & & & & $\begin{array}{c}24.1 \% ; 2 \% \\
\text { double } \\
\text { gloved }\end{array}$ & & $\begin{array}{c}97 \% \\
\text { midwifery } \\
\text { and } 47 \% \\
\text { dental } \\
\text { students }\end{array}$ & & \\
\hline 7 & $\begin{array}{c}\text { Asadpour et al. } \\
2013 \text { [85] }\end{array}$ & Iran & $\begin{array}{c}\mathrm{C} / \mathrm{S}, 135 \\
\text { physicians and } \\
\text { medical student }\end{array}$ & $\begin{array}{c}72.4 \% \\
(32.6 / 45)\end{array}$ & $\begin{array}{c}75.1 \% \\
(33.1 / 44)\end{array}$ & & & & & & & \\
\hline 8 & $\begin{array}{l}\text { Fashafsheh et } \\
\text { al. } 2015 \text { [86] }\end{array}$ & Palestine & C/S; 271 Nurses & $53.90 \%$ & & $\begin{array}{c}91.1 \% \text { had } \\
\text { good } \\
\text { practice }\end{array}$ & & & & & & \\
\hline 9 & $\begin{array}{c}\text { Halboub et al. } \\
2015 \text { [87] }\end{array}$ & Yemen & $\begin{array}{c}145 \text { dental } \\
\text { students }\end{array}$ & & & & - & $96.60 \%$ & $53.80 \%$ & $14 \%$ & - & - \\
\hline & & & & & & & & & & - & & \\
\hline 10 & $\begin{array}{c}\text { Qazi et al. } 2016 \\
\text { [75] }\end{array}$ & Parkistan & $\mathrm{C} / \mathrm{S}$ of $198 \mathrm{HCWs}$ & $\begin{array}{c}\text { Awarenes } \\
59.9 \%\end{array}$ & & & & $91 \%-100 \%$ & & & & $19.70 \%$ \\
\hline 11 & $\begin{array}{c}\text { Reda et al. } 2010 \\
\text { [2] }\end{array}$ & Ethiopia & $\begin{array}{c}\text { C/S Survey } 475 \\
\text { HCWs in } 10 \\
\text { Hospitals }\end{array}$ & & $53.10 \%$ & $\begin{array}{l}80 \% \\
\text { regular }\end{array}$ & & - & & & & \\
\hline & & & & & & - & - & & - & & - & - \\
\hline 12 & $\begin{array}{c}\text { Jakob et al. } \\
2015 \text { [88] }\end{array}$ & Ethiopia & C/S, 135 HCWs & - & & $42.20 \%$ & & & & & & $67.40 \%$ \\
\hline 13 & $\begin{array}{c}\text { Akudunan et al. } \\
1999 \text { [57] }\end{array}$ & USA & $\begin{array}{c}597 \text { HCWs in } 76 \\
\text { operating room } \\
\text { procedures }\end{array}$ & & - & & $\begin{array}{c}26 \% \\
\text { double } \\
\text { glove }\end{array}$ & & $\begin{array}{l}76 \% \text { any } \\
\text { form }\end{array}$ & & & - \\
\hline 14 & $\begin{array}{c}\text { Doebbling et al. } \\
2003 \text { [58] }\end{array}$ & USA & $\begin{array}{l}3223 \text { HCWS in } \\
\text { Community Hosp }\end{array}$ & & & $32 \%-54 \%$ & & & & - & $29-70 \%$ & $\begin{array}{c}32 \% \\
\text { nurse, } \\
28 \% \\
\text { doctors }\end{array}$ \\
\hline 15 & $\begin{array}{l}\text { Raghavendran } \\
\text { et al. } 2006 \text { [23] }\end{array}$ & $\begin{array}{c}\text { United } \\
\text { Kingdom }\end{array}$ & $\begin{array}{c}258 \text { HCWs (Drs, } \\
\text { Nurses \& } \\
\text { operating } \\
\text { Rm staff }\end{array}$ & - & & $\begin{array}{c}64 \% \\
\text { always, } \\
\text { Drs. } 31 \%\end{array}$ & $56.60 \%$ & & & & $57 \%$ & \\
\hline
\end{tabular}




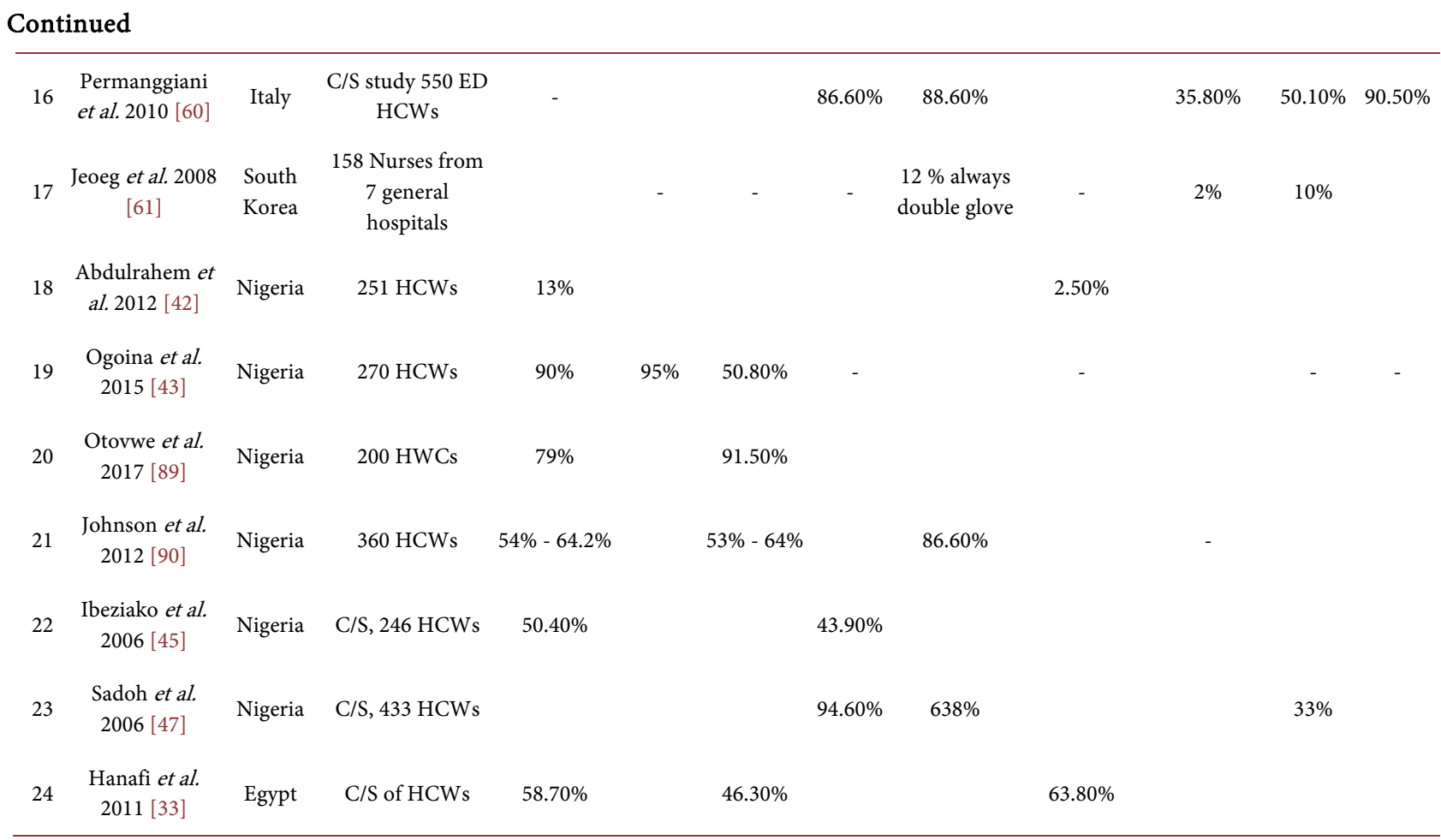

and reported that knowledge level in 90\%of respondents scored 12/19 (63.2\%) in scale of knowledge, but the score for practice was quite lower 5/19 (26.3\%) ( $\mathrm{p}=$ 0.049 ) [53]. The attitude to SP was poor as only $28 \%$ believed that SP was only necessary when treating patients with HIV. Jain et al. reported suboptimal knowledge (55.3\%) of SP in their cross sectional study of 329 nurses and 71 doctors in the same country with only $57 \%$ of them applying maximal barrier precautions [54]. Holla et al. in India reported quite high positive attitude to some components of SP such as Hand washing after removal of gloves, needle recapping, proper needle disposal and covering broken skin before attending to patients [55].

Two studies in Iran evaluated KAP among medical trainees. Barikari et al. reported mean knowledge score of $6.6 / 10(66 \%)$, practice at $18.8 / 30$ and attitude 10/16.6. while Askarian et al. noted that $85 \%$ of dental and midwifery students studied had received information on SP [16] [26]. Luo et al. in China studied 1444 nurses and noted 64.7 had 48.29/80 score for over all compliance of SP [56].

\section{Developed Countries}

Akduman et al. studied 597 HCWs in surgical specialties, observing them while performing procedures; he reported that only $28 \%$ double gloved, $32 \%$ wear regular eye glasses and $24 \%$ used no eye protection [57]. Doebbeling et al. studied 3223 HCWs in Iowa community hospitals and reported that $32 \%-54 \%$ practiced hand washing, $27 \%-70 \%$ avoided needle recapping, $30 \%$ had PI in 3 months, trained nurses are mostly at risk $32 \%$ as against $28 \%$ of physicians, $22 \%$ - 62\% under reported PI to appropriate authority [58]. Amin et al. reported low 
knowledge of SP across all domains with the least of $26.7 \%$ being in sharp injuries among students of King Faisal University in Saudi Arabia [59]. Raghavendran et al. reported on $258 \mathrm{HCWs}$ (involving doctors, nurses, operating room staff) in United Kingdom, $64 \%$ almost always followed SP but only $31 \%$ of doctors did [23]. Permeggiani et al. in their study of 550 randomly selected HCWs in Italy reported high knowledge of and attitude to SP but low compliance concerning Standard precautions [60]. Jeong et al. studied 158 scrub nurses in South Korea and reported poor compliance with SP, only $12 \%$ always double gloves, $2 \%$ always wear protective eye equipment and $10 \%$ always recap needles [61].

\section{Factors Affecting Compliance to Standard Precautions:}

Adinma et al. in their study of HCWs in Nnewi Nigeria reported lack of provision of adequate protective equipment as most important factor influencing compliance to SP. Others are Carelessness, lack of display of universal precautions guide line, emergency nature of intervention, insufficient water supply, patients perceived to be high risk for blood borne infection, pressure for time, use of protective equipment interfering with skill. Kio et al. reported in the same country among student nurses and staff, high job demand, unavailability of protective equipment, perception that patient involved did not pose a risk and high cost of equipment and materials required [62]. Nmadu et al. studied 32 Primary health workers and reported that lack of knowledge, perception of negative influence of personal protective equipment were individual factors for non compliance with SP. Heavy work load and Emergency situations were work related factors involved. Organizational factors include lack of PPE, lack of training and support from facility management [63]. Gebresilassie et al. in their study in Ethiopia reported that odd of good practice was 2.5 higher among young HCWs than older age, more likely to be reduced in males than female. Doctors and nurses had $80 \%$ and $70 \%$ odd of reduced practice than laboratory HCWs. There was 1.8 increase likelihood of SP practice when written communication is displaced [50]. Tesfay et al. in Ethiopia reported that extended working hours more than 40 hours/week, work experience less than 50 years and workers using protective equipment are more likely in $1.2,1.4$, and 1.6 to have occupational exposure; but that those that had been trained were 0.78 likely to be exposed [49]. Hanafi et al. in Egypt reported frequency of NSIs were reduced by access to devices with Safety features (OR 0.41 CI 95021 - 0.7), adherence to infection control guidelines(OR $0.42 \mathrm{CI} 950.26-0.71)$, having been trained in safety and appropriate work practice (OR $0.1495 \mathrm{CI} 0.03$ - 0.4), comfortable room temperature (OR 0.32 CI 950.06 - 0.67), available written protocol for prompt reporting (OR 0.37 CI 0.02 - 057), significant predictor of SP was knowledge of infection transmission following NSI [33].

Cheng et al. using indebt interview of HCWs noted that service providers reported selective adherence to SP in their daily practice [64]. Factors leading to non adherence to SP included lack of time to put on the protective equipment, that protective gear interfere with performance of medical procedure, lack of administrative support, heavy work. 
Efstathiou et al. studied 30 nurses selected from various department and reported that barriers to compliance include lack of protective equipment, use of some equipment reduce skill, patients discomfort or distress, too busy or perception that implementation of guide line is time consuming, that in providing nursing care to children that SP may be unnecessary, putting on equipment has negative effect on patient, nurses may be embarrassed using equipment nor commonly used in their environment, working experience and influence of physicians [65].

Vaughn et al. in their study of 1454 HCWs and infection control staff in Iowa USA reported that positive predictors of consistent adherence are Hours per full time employee (1.03), Frequency of SP education $(\mathrm{OR}=1.11)$, Facilities providing personal protective equipments and Met support need for safety. Negative predictive factors are Blood and body Fluid Precautions isolated Category (0.074) and Increased job demand $(\mathrm{OR}=0.9)$ [66]. Stringer et al. reported in their observational study of 3765 operation in Canada, that hand free technique was effective in preventing incidence of PI when blood loss is more than $100 \mathrm{mls}$ [67].

\section{Education and Practice of SP/UP}

Lutfe et al. in Bangladesh studied the role of education and training on practice of SP among $141 \mathrm{HCW}$ in secondary care hospitals, and reported significant improvement in compliance to SP and remarkable reduction in NSI, decreasing from $47.5 \%$ to $8.3 \%(p=0.0001)$ [68]. Obi et al. in their study of 304 HCWs working in a medical centre in Nigeria reported strong association between practice of SP and level of education ( $\mathrm{p}=0.001)$, training on SP, and how recently training has taken place [69].

Maheswari et al. in India studied the effect of structured training among class IV employees working in a college hospital and reported knowledge level increasing from 51\% to $93 \%$ [70]. Mahrous reported in his study, that score of knowledge and practice were increased after participation in education programs and that there was strong correlation between knowledge, practice and educational level [71].

Li li et al. in their study of 1760 health care providers from 40 county level hospitals in China reported that training on Universal precautions was associated with better knowledge of and adherence to UP and that perceived availability of UP supplies in the hospitals, UP training, knowledge and adherence were significantly associated with avoidance attitude towards PLWA in medical practice [72].

McCoy et al. studied 149 (62\%) community hospitals in Iowa and Virginia in United State of America and reported an association between ICPs assessment of HCWs training and workers who reported having sufficient information to comply with SP. Management commitment to SP training, leadership support, frequency of providing blood borne pathogens information safety climate were predictors for assessed adequacy of training. They concluded that institutional safety climate, leadership support and frequent education are important in HCWs training adequacy to monitor co-worker adherence to SP [73]. 


\section{Management Role in Practice of Standard Precautions}

Kingham et al. in their study of government and private hospitals in SearraLeone reported that only $20 \%$ of government owned hospitals had adequate sterile gloves and protective equipment. Suction pumps and aprons were available only in $30 \%-40 \%$ respectively, while the mission and private hospital were fully stocked [74]. Cheng et al. studied 33 health service providers and 27 health administrators from difference provinces and reported poor attitude of administrator to SP, with some thinking that it was the responsibility of the health care giver not to get hurt. One administrator retorted that those involved probably did not wash their hand enough and that non compliance may be due to non acceptance of SPs, indicating proven lack of leadership [64]. Did-Barista et al. studied 100 hospitals in Italy and reported 97\% and 98\% of hospitals provided specific information and education initiative respectively. All introduced at least one needle stick prevention device with average $4(1-11)$ centres implementing initiative to eliminate unnecessary needle injuries. All hospitals screened and vaccinated health workers against HBV [75]. Beckman et al. studied 153 of 240 hospitals in Iowa and Virginia on SP training and compliance and reported that $79 \%-80 \%$ monitor nurses and laboratory technicians but physicians are rarely monitored or trained, most common measures to prevent NSIs was use of needle stick prevention devices. They noted that over $50 \%$ of hospital used needless intravenous systems with larger hospitals using more [35].

Grimond et al. in their national survey and estimation of sharp injuries in USA reported that effective reduction strategies observed in hospitals with low incidence sharp are intense and repeated competence training, monthly instruction email, easy incident reporting, management involvement, immediate action on trends and Zero incidence as goal [24].

\section{Discussion}

Needle stick injuries and exposure to patients' blood remain a risk for potential infection acquisition among health care workers and other medically exposed persons. The occurrence varied among different professionals and institutions in different countries but it remains a problem across the globe. Wicker et al. in their study of patient admitted into the University hospital in Germany reported that the prevalence of blood borne infection for HBV, HCV and HIV were 9 times, 15 times, 82 times respectively higher than in the general populace [35]. This review shows that there is clear and continued risk for blood borne pathogen transmission through needle stick and accidental exposure to patients' blood in both developed and developing countries. The prevalence varied depending on the population of healthcare workers or students studied. It ranged from 17\% among HCWs in a tertiary hospital in India, [15] to 54\% and 72.1\% - 73\% among nurses and midwifery students in Iran [16]. Most common activity that led to NSIs among nurses was recapping of needle especially double hand recapping.

Nurses have been identified as the main professional group that are most at 
risk of needle stick injuries [20]-[27]. Surgeons though are at increased risk of NSIs but Physicians working in internal medicine department however are at most risk of contacting blood borne pathogen because greater number of their patients are infected with transmissible pathogens [37]. It is proper that preventive efforts target these groups, recapping should be strongly condemned and sharp containers made universally mandatory for disposable of sharp both in developed and developing countries. Incident reporting is essential components of NSI prevention not only for statistics but for post exposure prophylaxis. This is noted to be very low in most institutions in developing compared to developed countries [23] [30] [31]. Incident reporting should therefore be emphasised among other interventions for preventing needle stick injuries and exposure to patient's blood.

The safety of HCWs in their working environment necessitated the CDC to introduce a set of preventive measures that had metamorphosed from universal precaution to standard precaution as it is currently referred to. The knowledge of these measures among HCWs varied but in more recent literature was reported to be moderate to high across HCWs in both developing and developed nations. It is important to note that in some regions of some countries knowledge of SP still remain low [37]. Efforts are still needed in this regard. There appear to be a trend of increasing knowledge in South East region of Nigeria, comparing two studies 11 years apart that showed knowledge level raised from $50 \%$ to $76 \%$ [45] [46]. The practice or adherence to standard precautions however has remained low and lopsided and in some institutions poor [45] [48]. Some HCWs were found to be selective in their adherence to SP in the course of service delivery [60]. Most studies reported compliance rate of less than $60 \%$ and as low as $12 \%-26 \%$ in some components of SP [2] [46] [47] [48]. The current efforts therefore should be directed at identified measurable interventions to improve practice and adherence to standard precautions.

Education remained one of the identified factors that increases knowledge and improves compliance to SP [68] [69]. Most of the studies reviewed concluded by recommending more training and education on standard precautions and their applications. A significant improvement in compliance to SP and remarkable reduction in needle stick injuries was reported following education and training [68]. Repeated and regular training was suggested by the finding by Obi et al. in Nigeria that reported strong association between the levels of education and how recently training was done [69]. Tesfay et al. reported that those that have been trained are 0.78 likely to be exposed to NSIs. There was also the need for the training to be supervised to produce required result [49]. McCoy et al. in their study in USA reported association between ICP assessed HCWs training and workers having sufficient information to comply with standard precautions and they also concluded that frequent education, leadership support are relevant in health workers training adequacy [73].

Poor infrastructures and inadequate supplies remain a major hindrance to 
compliance to SP especially in developing countries. This was reported as the most common determinants of SP compliance in Nigeria, and has been reported as one of the negative predictor of adherence to standard precautions by other studies [62] [65]. Easily modifiable factors include lack of display of guideline for prevention of NSIs at points of health care services especially in area of high work demand, extended working hours, perception of HCWS of some patients being high or low risk, and that use of protective equipment interfere with the skill, increase job demand or pressure, comfortable working environment and room temperature and thinking that SP may not be needed when attending to paediatric cases. Methods that has been proven to be effective such as intense and repeated competence training, monthly instruction email, easy incident reporting, management involvement, immediate action on trends and Zero incidence as goal should be adopted.

In the surgical area the use of hand free techniques have been reported to reduce the risk of NSIs when blood loss is less than $100 \mathrm{mls}$, this should be adopted by surgeons during operation and further researches conducted to improve on this. The disposition of health system administrators may be a strong factor in provision of requisite preventive equipment and compliance to SP. Public hospitals especially in developing countries are less likely to provide needed materials for effective NSIs prevention. Health care managers in developed countries appear more disposed to put in place measures and necessary equipment to enable HCWs comply to SP and ensure appropriate supervision. Such attitude and actions should be universal among health care administrators.

\section{Conclusion}

Percutaneous injuries and accidental exposure to patient's blood continues to pose infection transmission risks among HCWs in both developed and developing countries. Despite appreciable knowledge of standard precautions the practice has remained low across the globe. Adherence to standard precautions is negatively affected by unavailability of equipment and infrastructure especially in developing countries, Carelessness on the part of HCWs, lack of display of SP guideline at points of service deliveries, working under pressure and emergency nature of some care, poor attitude of HCWS to use of SP, poor knowledge, lack of training and management support were some of the identified factors that militate against adherence to SP. Factors that had positive influence on practice of SP such as use of devices with safety features, adherence to infection control guideline, comfortable working environment, repeated and intense training, hand free techniques during operations, monthly instruction emails, easy reporting of incidents to appropriate authorities, involvement of health system administrators, should be adopted and promoted.

\section{Conflicts of Interest}

The authors declare no conflicts of interest regarding the publication of this paper. 


\section{References}

[1] Mashoto, K.O., Mubyazi, G.M., Mohamed, H. and Malebo, H.M. (2012) Self Reported Occupational Exposure to HIV and Factors Influencing Its Management Practice: A Study of Healthcare Works in Yumbi and Dotoma Hospitals, Tanzania. BMC Health Services Research, 13, Article No. 276. https://doi.org/10.1186/1472-6963-13-276

[2] Reda, A.A., Fisseha, S., Mengistie, B. and Vandeweerd, J.M. (2010) Standard Precautions: Occupational Exposure and Behavior of Healthcare Workers in Ethiopia. PLOS ONE, 5, e14420. https://doi.org/10.1371/journal.pone.0014420

[3] Salehi, A.S. and Garner, P. (2010) Occupational Injury History and Universal Precautional Awareness: A Survey in Kabul Hospital Staff. BMC Infectious Diseases, 10, Article No. 19. https://doi.org/10.1186/1471-2334-10-19

[4] CDC (1988) Update: Universal Precautions for Precaution of Transmission of Human Immunodeficiency Virus, Hepatitis B Virus and Other Bloodborne Pathogens in Health-Care Settings. Morbidity and Mortality Weekly Report, 37, 377-382.

[5] Prus-Ustun, A., Repiti, E. and Hutin, Y. (2005) Sharps Injuries: Global Burden of Disease from Sharps Injuries to Healthcare Workers. World Health Organization, Geneva.

[6] Tadesse, M. and Tadesse, T. (2010) Epidemiology of Needle Stick Injuries among Health-Care Works in Awassa City, Southern Ethiopia. Tropical Doctor, 40, 111-113. https://doi.org/10.1258/td.2009.090191

[7] Honda, M., Chompikul, J., Rattanapan, C., Wood, G. and Klungboonrong, S. (2011) Sharps Injuries among Nurses in a Thai Regional Hospital: Prevalence and Risk Factors. Journal of Occupational and Environmental Medicine, 2, 215-223.

[8] Nduka, I., Agunwa, E.N. and Nduka, E.C. (2012) Training on Universal Basic Precautions and Provision of Personal Protective Equipment: Effect on Prevention of Transmission of HIV in Hospital Setting. https://www.dissertation.npmcn.edu.ng/index.php/FMCPH/article/view/2480

[9] Oguntona, T.S., Adedeji, O.O. and Ogwusole, D. (2010) Awareness and Use of Personal Protective among Funeral Home Workers in Lagos State. Transnational Journal of Science and Technology, 2, 47-53.

[10] Tatelbaum, M.F. (2001) Needlestick Safety and Prevention Act. Pain Physician, 4, 193-195.

[11] European Union (2020) Directive 2010/32/EU-Prevention from Sharp Injuries in the Hospital and Healthcare Sector. https://osha.europa.eu/en/

[12] CDC. Universal Precautions for Prevention of Transmission of HIV and Other Blood Borne Infections. http://www.cdc.gov/

[13] Kalu, F.T.U. and Odusanya, O.O. (2012) Universal Precautions Study of Knowledge and Compliance among Doctors in Private Medical Practice in Lagos State, Nigeria. Nigerian Journal of General Practice, 10, 50-58.

[14] Okafor, C.I., Omousulu, D.N., Okafor, C.O., Ihekwaba, E.C. and Chineke, H.N. (2009) Prevalence and Attitude towards Needle Stick Injuries among Medical Practitioners in Nnewi, Southeast Nigeria. Journal of Medicine in the Tropics, 12, 26-29.

[15] Punia, R., Nair, S. and Shetty, R.S. (2014) Health Care Workers and Standard Precautions and Determinants of Compliance and the Emergency and Trauma Triage of a Tertiary Care Hospital in South India. International Scholarly Research Notices, 2014, Article ID: 685072. https://doi.org/10.1155/2014/685072

[16] Askarian, M., Malekmakan, L., Memish, Z.A. and Assadian, O. (2002) Prevalence of 
Needle Stick Injuries among Dental, Nursing and Midwifery Students in Shiraz, Iran. GSM Krankenhaushygiene Interdisziplinar, 7, Doc05.

[17] Talaat, M., Kandeel, A., El-Shoubary, W., Bodenschatz, C., Khairy, I., Oun, S. and Mahoney, F.J. (2003) Occupational Exposures to Needle Stick Injuries and Hepatitis B Vaccination Coverage among Health Care Workers in Egypt. American Journal of Infection Control, 31, 469-474. https://doi.org/10.1016/j.ajic.2003.03.003

[18] Jamu, S.M., Gabaitiri, L., Mudongo, K.K. and Mwaniki, N.K. (2016) Epidermiology of Percutaneous Exposure to Needlestick and Sharp Object Injuries in Botswana Public Health Sector. A Health Facility Cross Sectional Study. Global Journal of Medicine and Public Health, 5, 1-8.

[19] Parithram, V.K., Murali, R., Krishna, M., Kumar, V., Yalamalli, M. and Kumar, V. (2015) Knowledge, Attitude and Practice of Needle Stick and Sharps Injuries among Dental Professional of Bangalore India. Journal of International Society of Preventive and Community Dentistry, 5, 407-412. https://doi.org/10.4103/2231-0762.165932

[20] Moodley, I. and Naidoos, S. (2015) Percutaneous Exposure Incidence, Prevalence, Knowledge and Perception of Dental Personal and Students at a Dental Training Site in KwaZulu-Natal. Journal of the South African Dental Association, 70, 334-339.

[21] Guest, M., Kable, A.K., Bogged, M.M. and Friedewald, M. (2014) Nurses Sharps Including Needle Sticks Injuries in Public and Private Health Care Facilities in South Wales, Australia. Health Care Infection, 19, 65-75. https://doi.org/10.1071/HI13044

[22] Izadi, N., Chavoshi, F. and Sadeghi, M. (2015) Needlesticks and Sharps Injuries among the Personnel of Baharlou Hospital in Tehran, Iran. Jundishapur Journal Health Sciences, 7, e30649. https://doi.org/10.17795/jihs-30649

[23] Raghavendran, S., Barry, H.S., Leith, S. and Budd, J.M. (2006) Needle Sticks Injuries, a Comparison of Practice and Attitude in Two UK District General Hospitals. Anaesthesia, 61, 867-872. https://doi.org/10.1111/j.1365-2044.2006.04751.x

[24] Grimmond, T. and Good, L. (2014) EXPO. S.T.O.P.: A National Survey and Estimate of Sharp Injuries and Mucocutaneous Blood Exposure among Health Care Workers in USA. Survey Result 2013, Association of Occupational Health Professionals in Healthcare. https://www.aohp.org/aohp/

[25] Venier, A.G., Vincent, A., L'Herteau, F. and Florez, N. (2007) Surveillance of Occupational Blood and Body Fluid Exposure among French Healthcare Workers in 2004. Infection Control \& Hospital Epidemiology, 27, 1196-1201. https://doi.org/10.1086/520742

[26] Barikani, A. and Afaghi, A. (2012) Knowledge, Attitude and Practices toward Standard Isolation Precautions along Iranian Students. Global Journal of Health Science, 4, 142-144. https://doi.org/10.5539/gihs.v4n2p142

[27] Smith, D.R., Leggat, P.A. and Takahashi, K. (2005) Percutaneous Exposure Incidents among Australian Hospital Staff. International Journal International Journal of Occupational Safety and Ergonomics, 11, 323-330. https://doi.org/10.1080/10803548.2005.11076654

[28] Bidira, K., Woldie, M. and Nemera, G. (2014) Prevalence and Predictors of Needle Stick Injury among Nurses in Public Hospitals of Jimma Zone, South West Ethiopia. International Journal of Nursing and Midwifery, 6, 90-96

[29] Bolarinwa, O.A., Asowande, A. and Akintimi, C.I. (2011) Needle Stick Injury Pattern among Health Workers in Primary Health Care Facilities in Ilorin. Nigeria Academic Research International, 1, 419-427

[30] Nwankwo, T.O. and Aniebue, U.U. (2011) Percutaneous Injuries and Accidental 
Blood Exposure in Surgical Residents: Awareness and Use of Prophylaxis in Relation to HIV. Nigerian Journal of Clinical Practice, 14, 34-37. https://doi.org/10.4103/1119-3077.79237

[31] Denic, L.M., Maksimonic, N., Marusic, V., Vucicevic, J., Ostric, I. and Djuric, D. (2015) Occupational Exposure to Blood and Body Fluids among Health Workers in Serbia. Medical Priciples and Practice, 24, 36-41. https://doi.org/10.1159/000368234

[32] Perez-Diaz, C., Calixto, O., Faccini-martinez, A.A., Bravo-Ojeda, J.S., Botero-Gźarcia, C.A., Uribe-Pardo, E., Mantilla-Florez, Y.F., et al. (2015) Occupational Exposure to Blood Borne Pathogens among Healthcare Workers: A Cross Sectional Study of Registry in Clombia. Journal of Occupational Medicine and Toxicology, 10, Article No. 45. https://doi.org/10.1186/s12995-015-0088-Z

[33] Hanafi, M.I., Mohamed, A.M., Kassem, M.S. and Shaw, K.M. (2011) Needle Stick Injuries among Health Care Workers of University of Alexandria Hospitals. Eastern Mediterranean Health Journal, 17, 26-35. https://doi.org/10.26719/2011.17.1.26

[34] Omar, A.A., Abdo, N.M., Salama, M.F. and Al-Mousa, H.H. (2015) Occupational Injuries Prone to Infection Risk amongst Healthcare Personnel in Kuwait: A Retrospective Study. Medical Principles and Practice, 24, 123-128. https://doi.org/10.1159/000369462

[35] Berkman, S.E., Vaughn, T.E., McCoy, K.D., Torner, J.C., Woolson, R.F. and Doebbeling, B.N. (2011) Hospital Bloodborne Pathogens: Program Characteristics and Blood and Body Fluid Exposure Rates. Infection Control \& Hospital Epidemiology, 22, 73-82. https://doi.org/10.1086/501867

[36] Rice, B.D., Tomkins, S.E. and Ncube, F.M. (2015) Sharp Truth: Health Care Workers Remain at Risk of Blood Borne Infection. Occupational Medicine, 65, 210-214. https://doi.org/10.1093/occmed/kqu206

[37] Wicker, S., Cinatl, J., Berger, A., Doerr, H.W., Gottschalk, R. and Rabenau, H.F. (2008) Determination of Risk of Infection with Blood-Borne Pathogens Following a Needle Stick Injury in Hospital Workers. Annals of Occupational Hygiene, 52, 615-622.

[38] Yoshikawa, T., Wada, K., Lee, J.J., Mitsuda, T., Kidouchi, K., Kurosu, H., et al. (2013) Incidence Rate of Needlestick and Sharps Injuries in 67 Japanese Hospitals: A National Surveillance Study. PLoS ONE, 8, e77524. https://doi.org/10.1371/journal.pone.0077524

[39] Shiao, J., Guo, L. and McLaw, M.L. (2002) Estimation of the Risk of Bloodborne Pathogens to Health Care Workers after a Needlestick Injury in Taiwan. American Journal of Infection Control, 30, 15-20. https://doi.org/10.1067/mic.2002.119928

[40] Nouetchognou, J.S., Ateudjieu, J., Jemea, B. and Mbanya, D. (2016) Accidental Esposure to Blood and Body Fluids among to Blood and Body Fluids among Health Care Workers in a Referral Hospital of Cameroon. BMC Reserach Notes, 9, Article No. 94. https://doi.org/10.1186/s13104-016-1923-8

[41] Mbaisi, E.M., Nganga, Z., Wanzala, P. and Omolo, J. (2013) Prevalence and Factors Associated with Percutaneous Injuries and Splash Exposure, among Health Workers in a Provincial Hospital Kenya, 2010. Pan African Medical Journal, 14, Article No. 10. https://doi.org/10.11604/pamj.2013.14.10.1373

[42] Abdulraheem, I.S., Amodu, M.O., Saka, M.J., Bolarinwa, O.A. and Uthman, M.M.B. (2012) Knowledge, Awareness and Compliance with Standard Precaution among Health Workers in North Eastern Nigeria. Community Medicine \& Health Education, 2, 131.

[43] Ogoina, D., Pondei, K., Adetunji, B., Chima, G., Isichei, C. and Gidado, S. (2015) 
Knowledge, Attitude and Practice of Standard Precaution of Infection Control by Hospital Workers in Two Tertiary Hospitals in Nigeria. Journal of Infection Prevention, 16, 16-22. https://doi.org/10.1177/1757177414558957

[44] Bolaji-Osagie, S.O. and Adeyemo, F.O. (2015) The Knowledge and Practice of Universal Precautions amongst Midwives in Central Hospital Benin City. Journal of Public Health and Epidemiology, 7, 331-336. https://doi.org/10.5897/JPHE2015.0732

[45] Ibeziakor, S.N. and Ibekwe, R.C. (2006) Knowledge and Practice of Universal Precaution in Tertiary Health Facility. Nigerian Journal of Medicine, 16, 250-254. https://doi.org/10.4314/njm.v15i3.37223

[46] Ndu, A.C. and Arinze-Onyia, S.U. (2017) Standard Precaution Knowledge and Adherence: Do Doctors Differ from Medical Laboratory Scientists? Malawi Medical Journal, 29, 294-300. https://doi.org/10.4314/mmj.v29i4.3

[47] Sadoh, W.E., Fawole, A.O., Sadoh, A.E., Oladimeji, S.O. and Sotiloye, O.S. (2006) Practice of Universal Precautions among Health Workers. Journal of National Medical Association, 98, 722-725.

[48] Amoran, O.E. and Onwube, O.O. (2013) Infection Control and Practice of Standard Precautions among Healthcare Workers in Northern Nigeria. Journal of Global Infectious Diseases, 5, 156-163. https://doi.org/10.4103/0974-777X.122010

[49] Tesfay, F.A. and Habtewold, T.D. (2014) Assessment of Prevalence and Determinants of Occupational Exposure to HIV Infection among Healthcare Workers in Selected Health Institutions in Debre Berhan Town, North Shoa Zone, Amhara Region, Ethiopia, 2014. AIDS Research and Treatment, 2014, Article ID: 731848. https://doi.org/10.1155/2014/731848

[50] Gebresilassie, A., Kumei, A. and Yemane, D. (2014) Standard Precautions Practice among Health Care Workers in Public Health Facilities of Mekelle Special Zone, Northern Ethiopia. Journal of Community Medicine \& Health Education, 4, 286.

[51] Eskander, H.G., Mossy, W.Y.M. and Elfeky, H.A.A. (2013) Intensive Care Nurse's Knowledge and Practices Regarding Infection Control Standard Precautions at a Selected Egyptian Cancer Hospital. Journal of Education and Practices, 4, 160-174

[52] Wasswa, P., Balwadda, S.O., Buregyeya, E., Gitta, S.N., Anguzu, P. and Nuwsha, F. (2015) Implementation of Infection Control in Health Facilities in Asia District, Uganda: A Cross Sectional Study. BMC Infectious Diseases, 15, Article No. 268. https://doi.org/10.1186/s12879-015-0999-4

[53] Pati, S., Dwain, S., Patida, S.S. and Hussain, M.A. (2013) Preliminary Inquiry: Adherence to Universal Precaution Methods among Healthcare Providers in a Government Hospital in Odisha India. Clinical Health Promotion, 3, 42-45. https://doi.org/10.29102/clinhp.13007

[54] Jain, M., Dogra, V., Mishra, B., Thakur, A. and Loomba, P.S. (2012) Infection Control Practices among Doctors and Nurses in a Tertiary Care Hospital. Annals of Tropical Medicine and Public Health, 5, 29-33. https://doi.org/10.4103/1755-6783.92877

[55] Holla, R., Kandian, T., Unnikrishan, B., Rekhat, T., Mithra, P., et al. (2014) Perception and Practices of Standard Precautions among Healthcare Professionals at Tertiary Care Hospitals in Coastal South India. Asian Journal of Pharmaceutical and Clinical Research, 17, 101-104.

[56] Lou, Y., He, G., Zhuo, J. and Lou, Y. (2010) Factors Impacting Compliance with Standard Precautions in Nursing, China. International Journal of Infectious Diseases, 14, e1106-e1114. https://doi.org/10.1016/j.ijid.2009.03.037 
[57] Akduman, D., Kim, L.E., Parks, R.L., L’Ecuyer, B.B. and Fraser, V.J. (1999) Use of Personal Protective Equipment and Operating Room Behavior in Four Surgical Subspecialties: Personal Protective Equipment and Behavior in Surgery. Infection Control and Hospital Epidemiology, 20, 110-114.

[58] Doebbeling, B.N., Vaugh, T.E., Mcloy, K.D., Beekmann, S.E., Woolson, R.F., Ferguson, K.J. and Torner, J.C. (2003) Percutaneous Injury, Blood Exposue and Adherence to Standard Precaution: Are Hospital Based Health Care Providers Still at Risk? Clinical Infectious Disease, 37, 1006-1013. https://doi.org/10.1086/377535

[59] Amin, T.T., Al Noaim, K.I., Bu Saad, M.A. and Al Malik, T.A. (2013) Standard Precautions and Infection Control Medical Student Knowledge and Behaviour at a Saudi University: The Need for Change. Global Journal of Health Sciences, 13, 114-125.

[60] Parmeggiani, C., Abbate, R., Marinelli, P. and Angelillo, I.F. (2010) Healthcare Workers and Health Care Associated Infection: Knowledge, Attitudes, and Behavior in Emergency Departments in Italy. BBC Infectious Diseases, 10, Article No. 35. https://doi.org/10.1186/1471-2334-10-35

[61] Jeong, I., Cho, J. and Park, S. (2008) Compliance with Standard Precautions among Operating Room Nurses in South Korea. American Journal of Infection Control, 36, 739-742. https://doi.org/10.1016/j.ajic.2008.04.253

[62] Adinma, E.D., Ezeama, C., Adinma, J.I. and Asuzu, M.C. (2013) Knowledge and Practise of Universal Precautions against Blood Borne Pathogens amongst House Officers and Nurses in Tertiary Health Institutions in Southeast Nigeria. Nigerian Journal of Clinical Practice, 12, 398-402

[63] Nmadu, A.G., Kabir, S. and Istifanus, A.J. (2015) Barriers to Universal Precautions Compliance among Primary Health Care Workers in Kaduna State Nigeria. A Qualitative Study. Journal of Community and Health Sciences, 10, 44-54

[64] Wu, S., Li Li, Wu, Zu, Y., Cao, G.J., Lin, C.G., Yan, Z.H., et al. (2008) Universal Precautions in Era of HIV/AIDS: Perception of Health Service Providers in Yunnan, China. AIDS and Behavior, 12, 806-814. https://doi.org/10.1007/s10461-007-9278-8

[65] Efstathiou, G., Papastavrou, E., Raftopoulo, V. and Merkouris, A. (2011) Factors Influencing Nurses Compliance with Standard Precautions in Order to Avoid Occupational Exposure to Microorganisms: A Focus Group Study. BMC Nursing, 10, Article No. 1. https://doi.org/10.1186/1472-6955-10-1

[66] Vaughn, T.E., McCoy, K.D., Berkman, S.E., Woolson, R.E., Torner, J.C. and Doebbeling, B.N. (2004) Factors Promoting Consistent Adherence to Safe Needle Precautions among Hospital Workers. Infection Control \& Hospital Epidemiology, 25, 548-555. https://doi.org/10.1086/502438

[67] Stringer, B., Infante-Rivard, C. and Hanley, J.A. (2002) Effectiveness of the HandFree Technique in Reducing Operating Theatre Injuries. Occupational and Environmental Medicine, 59, 703-707. https://doi.org/10.1136/oem.59.10.703

[68] Lutfe, A., Vashkar, S.M.K., Mowla, S.M., Dewar, H., Kamrul, I. and Ataya, R.M. (2015) Increasing Occupational Safety of Healthcare Workers of Bangledesh from Needle Stick Injuries through Education and Training. Journal of Microbiology, Immunology, and Infection, 48, s53. https://doi.org/10.1016/j.jmii.2015.02.104

[69] Obi, I.E., Agunwa, C.C., Omotowo, B.I., Azuike, F.C., Ndu, A.C. and Umeobieri, A.K. (2017) The Practice of Universal Precautions among Health Workers in South East Nigeria: What Factors Matter? International Journal of Medicine and Health Developmen, 22, 45-53

[70] Maheswari, S. and Muthamilselvi, G. (2014) Assess the Effectiveness of Structure 
Teaching Programme on Universal Precaution among Calss IV Employees Working at Aarupadai Veedu Medical College and Hospital, Puducherry, India. American Journal of Nursing Research, 2, 26-30.

[71] Mahrous, M.F. (2016) Effect of Universal Precautions Intervention Program on Nurses Knowledge and Practice towards Hepatitis B Virus. Academic Research International, 7, 1-10.

[72] Li, L., Lin, C.G., Wu, Z.Y., Guan, J.H., Via, M.N. and Yan, Z.H. (2011) HIV Related Avoidance and Universal Precautions in Medical Settings: Opportunities to Intervene. Health Services Research, 46, 617-631. https://doi.org/10.1111/j.1475-6773.2010.01195.x

[73] McCoy, K.D., Beekmann, S.E., Ferguson, K.J., Vaughn, T.E., Torner, J.C., Woolson, R.F., et al. (2001) Monitoring Adherence to Standard Precautions. American Journal of Infection Control, 29, 24-31. https://doi.org/10.1067/mic.2001.111226

[74] Kingham, T.P., Kamara, T.B., Daoh, K.S., Ikabbia, S. and Kusher, A.L. (2009) Universal Precautions and Surgery in Sierra Leone, the Unprotected Work Force. World Journal of Surgery, 33, 1194-1196. https://doi.org/10.1007/s00268-009-0014-6

[75] Qazi, A.R., Siddiqui, F.A., Faridi, S., Nadeem, U., Umer, N.I., Mohsini, M.M., et al. (2016) Comparison of Awareness about Precautions for Needle Stick Injuries: A Survey among Health Care Workers at a Tertiary Care Centre in Pakistan. Patient Safety in Surgery, 10, Article No. 19. https://doi.org/10.1186/s13037-016-0108-7

[76] Kuruuzum, Z., Elmali, Z., Gunay, S. and Yapan, Z. (2008) Occupational Exposure to Blood and Body Fluids among Health Care Workers: A Questionnaire Survey. Mikrobiyoloji Bulteni, 42, 61-69.

[77] Laisser, R.M. and Ng'Home, J.F. (2017) Reported Incidence and Factors Associated with Percutaneous Injuries and Splash Exposure among Healthcare Workers in Kahama Districts, Tanzania. Tanzania Journal of Health Research, 19, 1-8. https://doi.org/10.4314/thrb.v19i1.4

[78] Hysieh, W., Chiu, N., Lee, C. and Huang, F. (2006) Occupational Blood and Infectious Body Fluid Exposures in a Teaching Hospital, a Three Year Review. Journal of Microbiology, Immunology and Infection, 39, 321-327

[79] Wang, Y.J., Meng, Z.H., Zheng, X.F., Jang, X.X., Sang, L.Y., Du, X.M., et al. (2015) The Status of Occupational Blood and Infectious Body Fluid Exposures in Five Blood Centres in China: A 5 Year Review. Transfusion Medicine, 25, 399-405. https://doi.org/10.1111/tme.12262

[80] Bharduaji, A., Sivapthasundaram, N., Yusof, M.F., Minghat, A.H., Swe, K.M.M. and Sinha, N.K. (2014) The Prevalence of Accidental Needlestick Injuries and Their Reporting among Healthcare Workers in Orthopaedic Wards in General Hospital Melaka, Malaysia. Malaysia Orthopaedic Journal, 8, 6-13.

https://doi.org/10.5704/MOJ.1407.009

[81] Moro, P.L., Moore, A., Balcacer, P., Montero, A., Diaz, D., Gomez, V., et al. (2007) Epidemiology of Needle Stick Injuries and Injection Safety Practice in the Dominican Republic. American Journal of Infection Control, 35, 552-559. https://doi.org/10.1016/j.ajic.2007.06.001

[82] Zaidi, M.A., Griffiths, R., Beshyal, S.A., Myers, J. and Zaidi, M.A. (2012) Blood and Body Fluid Exposure Related to Knowledge, Attitude and Practices of Hospital Based Health Care Providers in United Emirates. Safety and Health at Work, 3, 209-215. https://doi.org/10.5491/SHAW.2012.3.3.209

[83] Falafel, M., Karydis, L. and Kostogiannou, L. (2007) Percutaneous Exposure Inci- 
dents of the Health Care Personnel in a Newly Founded Tertiary Hospital: A Prospective Study. PLoS ONE, 2, e194. https://doi.org/10.1371/journal.pone.0000194

[84] Das, M. and Ojah, J. (2016) The Knowledge and Practice of Universal Precaution among the Interns of Gauhati Medical College: A Cross-Sectional Study. Indian Journal of Basic and Applied Medical Research, 5, 805-815.

[85] Asadpour, M., Vazirinejad, R., Esmaeili, A., Bazyar, S.H. and Falla, A. (2013) The Knowledge, Attitude and Practice of Physicians and Medical Srudents of Ratsanjan University of Medical Sciences, Iran, Regarding Standard Precautions. Journal of Occupational Health and Epidemiology, 2, 107-113. https://doi.org/10.18869/acadpub.johe.2.3.107

[86] Fashafsheh, I., Ayed, A., Eqtait, F. and Harazneh, L. (2015) Knowledge and Practice of Nursing Staff towards Infection Control Measures in the Palestinian Hospitals. Journal of Education and Practice, 6, 79-80.

[87] Halboub, E.S., Al-Maweri, S., Al-Jamaei, A.A., Tarakji, B. and Al-Soneidar, W.A. (2015) Knowledge, Attitudes and Infection Control among Dental Students at Sana'a University, Yemen. Journal of International Oral Health, 7, 15-19.

[88] Jakob, E., Lamaro, T. and Henok, A. (2015) Knowledge Attitude and Practice toward Infection Control Measures among Mizan-Aman General Hospital Workers, South West Ethiopia. Journal of Community Medicine and Health Education, 5, Article ID: 1000370.

[89] Otovwe, A. and Adidatimi, P.O. (2017) Knowledge, Attitude and Practice of Standard Precautions among Healthcare Workers in Federal Medical Centre Yenagoa. Nigeria. Journal of Pharmacy and Biological Sciences, 12, 79-86.

[90] Johnson, O.E., Asuzu, M.C. and Adebiyi, A.O. (2013) Knowledge and Practice of Universal Precaution among Professionals in Public and Private Health Facilities in Uyo, Southern Nigeria-A Comparative Study. Ibom Medical Journal, 5, 9-19. 